\title{
PELAKSANAAN PEBINAAN KREATIVITAS SISWA DALAM KEGIATAN EKSTRAKURIKULER KURSUS KADER DAKWAH (KKD) DI MAN 2 MODEL MEDAN
}

\author{
Haidir $^{1}$, Rizki Ananda², Qurrota A'yuna Tambunan³, \\ Yusri Purnama Anju Nasution ${ }^{4}$ \\ Program Studi Magister PAI Reguler Tahun 2019, Fakultas tarbiyah dan Keguruan, Universitas Islam \\ Negeri Sumatera Utara \\ * Penulis Korespodensi: haidir@uinsu.ac.id
}

\begin{abstract}
Abstrak
Penelitian ini bertujuan untuk mengetahui (1) Program-program pelaksanaan pembinaan kreativitas dalam kegitan ekstrakurikuler Kursus Kader Dakwah (KKD) di MAN 2 Model Medan dan (2) Mengetahui peluang dan hambatan dalam kegiatan ekstrakurikuler KKD d iMAN 2 Model Medan. Penelitian ini merupakan penelitian deskriptifkualitatif. Subjek penelitian ini adalah kepala Madrasah, guru pembimbing dan siswa. Adapun hasil penelitian bahwa: (1) Program-program ekstrakurikuler KKD dalam bidang keagamaan dan Dakwah melatih retorika dakwah secara Islami, serta mengkaji Alquran, Mentoring (Halaqoh), Tahsin Alquran, Pelatihan Pidato, Pelatihan Jurnalistik, Syarhil dan Fahmil Alquran, Silaturrahmi, Gebyar Kreativitas Muharram, Safari Ramadhan, dan Rihlah. (2) Peluang yang besar terbukti dengan adanya antusias yang besar dari siswa yang mengikutinya dan dukungan yang kuat dari pihak madrasah, sehingga mereka dapat mengembangkan bakat yang mereka miliki terutama bakat retorika dakwah serta kegiatan KKD dapat terlaksana dengan baik dan hambatan yang tidak terlalu berarti.
\end{abstract}

\section{Kata Kunci : Ektrakurikuler Kursus Kader Dakwah, Pembinaan Kreativitas}

\begin{abstract}
This study aims to determine (1) Programs for the implementation of creativity coaching in extracurricular activities of the Da'wah Cadre Course (KKD) in MAN 2 Medan Model and (2) Knowing the opportunities and obstacles in the KKD extracurricular activities in MAN 2 Medan Model. This research is a qualitative descriptive study. The subjects of this study were the headmaster of Madrasas, supervisors and students. The results of the study are: (1) KKD extracurricular programs in the field of religion and Da'wah train Islamic rhetoric, as well as reviewing the Koran, Mentoring (Halaqoh), Tahsin Alquran, Speech Training, Journalistic Training, Sharhil and Fahmil Alquran, Silaturrahmi, Gebyar Creativity Muharram, Safari Ramadhan, and Rihlah. (2) The great opportunity is proven by the great enthusiasm of students who follow it and strong support from the madrasa, so that they can develop their talents, especially the talents of rhetoric and propaganda KKD Keywords: Extracurricular Da'wah Cadre Course, Creativity Developmentactivities can be carried out well and obstacles are not too significant.
\end{abstract}

\section{Keywords: Extracurricular Da'wah Cadre Course, Creativity Development.}

\section{PENDAHULUAN}

Pendidikan bertujuan untuk meningkatkan kecerdasan, keterampilan, kemampuan, peningkatan potensi diri dan dapat membentuk pribadi diri yang bertanggung jawab, cerdas dan kreatif.Sesuai dengan tujuan pendidikandalam undang-undang Sistem Pendidikan Nasional (Sisdiknas) Bab II Pasal 3 bahwasannya :

"Pendidikan Nasional berfungsi mengembangkan kemampuan dan membentuk watak serta peradaban bangsa yang bermartabat dalam rangka mencerdaskan kehidupan bangsa, bertujuan untuk berkembangnya potensi peserta didik agar menjadi manusia yang beriman dan bertaqwa kepada Tuhan Yang Maha Esa, berakhlak mulia, sehat, berilmu, cakap, kreatif, mandiri dan menjadi warga negara yang demokratis serta bertanggung jawab.”

Kegiatan pendidikan di madrasah terbagi menjadi dua bagian, yaitu kegiatan intrakurikuler dan kegiatan ekstrakurikuler. Kegiatan intrakurikuler dilaksanakan pada saat berlangsungnya jam sekolah, sedangkan kegiatan ekstrakurikuler dilaksanakan di luar jam pelajaran di sekolah. Kedua kegiatan tersebut sama pentingnya dan saling melengkapi. 
Sistem pendidikan nasional mengenal istilah ekstrakurikuler, yakni kegiatan diluar jam akademis sebagai wadah penyaluran minat dan bakat anak didik. Hal ini berdasarkan pada Peraturan Menteri Pendidikan dan Kebudayaan Republik Indonesia Nomor 62 Tahun 2014 tentang kegiatan ekstrakurikuler pada pendidikan dasar dan pendidikan menengah. Kegiatan Ekstrakurikuler adalah kegiatan kurikuler yang dilakukan oleh peserta didik di luar jam belajar kegiatan intrakurikuler dan kokurikuler, di bawahbimbingan dan pengawasan satuan pendidikan.

Kegiatan ekstrakurikuler merupakan salah satu program yang sangat tepat dipilih oleh peserta didik dalam mengembangkan bakat, minat, dankeunikan di dalam diri seseorang untuk meraih prestasi yang bermakna bagi diri dan masa depan seseorang. Salah satu ekstrakurikuler yang bersifat keagamaan yaitu KKD yang dilaksanakan dengan cara memberikan pengetahuan kepada peserta didik seputar ilmu-ilmu keagamaan yang bertujuan agar peserta didik mampu mengetahui ajaran Islam dan mampu mengaplikasikannya dalam kehidupan seharihari.

Kegiatan ekstrakurikuler KKD merupakan bagian dari kegiatan pendidikan Islam.Pendidikan Islamadalah upaya sadar dan terencana dalam menyiapkan peserta didik untuk mengenal, memahami, menghayati, mengimani, bertakwa, berakhlak mulia, mengamalkan ajaran agama Islam dari sumber utamanya kitab suci Alqur'an dan AlHadis, melalui kegiatan bimbingan, pengajaran, latihan, serta penggunaan pengalaman. (Ramayulis, $2005: 21)$

Peserta didik adalah manusia yang memerlukan bantuan dan pertolongan orang lain, dia tidak bisa hidup sendiri tanpa pertolongan. Pertolongan sejak awal kepadanya adalah bagian dari pendidikan. Pertolongan yang diberikan kepadanya ada dalam dua bentuk pertolongan, yaitu : perawatan fisik berupa memberi makanan yang bergizi, merawat fisiknya dengan sebaik-baiknya, memeriksa kesehatan dan merawatnya, menyediakan tempat yang layak, pakaian yang pantas untuk dipakainya, demikian seterusnya, dan selanjutnya memberikan pendidikan jiwanya. Ditinjau dari segi rohani manusia, berupa pendidikan terhadap seluruh potensi rohani manusia yang telah diberikan Allah kepadanya.

Sekolah atau Madrasah merupakan salah satu lembaga pendidikan yang dapat membina dan mengembangkan kreativitas siswa.Di sekolah atau madrasah inilah banyak kegiatan ekstrakurikuler yang bersifat religius yang dapat membina dan mengembangkan kreativitas siswa.Hanya saja dalam kenyataannya, masih banyak terdapat sekolah atau madrasah yang tidak menyelenggarakan kegiatan ekstrakurikuler keagamaan khususnya KKD, sehingga potensi peserta didik kurang dikembangkan secara optimal. Begitu juga halnya dengan madrasah yang sudah membentuk kegiatan ekstrakurikuler KKD, tetapi belum sepenuhnya diberdayakan sebagai pusat pengkajian pendidikan Islam. Hal ini terlihat dari pola manajemen yang belum mapan, strategi jitu pembelajaran yang belum diterapkan, ragam media yang tidak digunakan, berbagai sumber belajar yang belum maksimal dimanfaatkan, dan kurangnya semangat peserta didik dalam membina krativitasnya pada ekstrakurikuler KKD.

Fokus penelitian ini berdasarkan latar belakang masalah yaitu yang berkaitan dengan Pelaksanaan Kegiatan ekstrakurikuler Kursus Kader Dakwah yang meliputi Program-program dan hambatan dalam pelaksanaan kegiatan ekstrakurikuler KKD di MAN 2 Model Medan.vBerdasarkan fokus penelitian tersebut maka peneliti diarahkan untuk: Bagaimana bentuk program-program pelaksanaan kegiatan ekstrakurikuler KKD dalam membina kreativitas siswa di MAN 2 Model Medan Medan, dan Apa saja peluang dan hambatan dalam pelaksanaan kegiatan ekstrakurikuler KKD dalam membina kreativitas siswa di MAN 2 Model Medan Medan.

\section{Kajian Teori}

\section{Pengertian Pembinaan Kreativitas}

Kata pembinaan berasal dari kata "bina" yang berarti proses, cara, membangun, dan mendirikan.Sedangkan kata kreativitas menurut Kamus Bahasa Indonesia disebutkan bahwa pengertian dari kreativitas adalah "Penuh Daya Cipta".( Sagoya, $1995: 25$ )

Sedangkan menurut Utami Munandar (2010 : 18) menyatakan bahwa yang dimaksud dengan kreativitas adalah suatu gaya hidup yaitu suatu cara mempersepsi dunia. Hal ini sejalan dengan pendapat Clark Moustakis seorang psikolog humanistic yang terkemuka di dunia menjelaskan bahwa yang dimaksud dengan kreativitas adalah "Pengalaman mengekspresikan identitas individu dalam bentuk terpadu dalam hubungan dengan diri sendiri, dengan alam, dan dengan orang lain".

\section{Kegiatan Ekstrakurikuler}

\section{a. Pengertian Kegiatan Ekstrakurikuler}

Berdasarkan Peraturan Menteri Pendidikan Nasional Republik Indonesia Nomor 39 Tahun 2008 tentang Pembinaan Kesiswaan kegiatan ekstrakurikuler merupakan salah satu jalur pembinaan kesiswaan. Kegiatan ekstrakurikuler yang diikuti dan dilaksanakan oleh siswa baik di sekolah maupun di luar sekolah, bertujuan agar siswa dapat memperkaya dan memperluas diri. Memperluas diri 
dapat dilakukan dengan memperluas wawasan pengetahuan dan mendorong pembinaan sikap dan nilai-nilai.

\section{b. Jenis Jenis Kegiatan Ekstrakurikuler}

Secara umum, kegiatan ekstrakurikuler dapat dibagi menjadi dua jenis, yaitu :

1) Kegiatan ekstrakurikuler yang bersifat berkelanjutan, yaitu jenis kegiatan ekstrakurikuler yang dilaksanakan secara terusmenerus selama satu periode tertentu. Untuk menyelesaikan satu program kegiatan, biasanya ekstrakurikuler ini memerlukan waktu yang lama.

2) Kegiatan ekstrakurikuler yang bersifat periodik atau sesaat, yaitu ekstrakurikuler yang dilaksanakan pada waktu-waktu tertentu saja.

\section{c. Ruang Lingkup Kegiatan Ekstrakurikuler} Adapun ruang lingkup dari kegiatan ekstrakurikuler, yaitu :
1) Sebagai
pengembangan

pengetahuan dan kemampuan penalaran siswa.
2)
Sebagai
pengembangan

keterampilan melalui hobi dan minat siswa.

3) Sebagai pengembangan sikap yang menunjang program kurikuler dan kokurikuler. (Johar, 2012)

\section{d. Tujuan Kegiatan Ekstrakurikuler}

Adapun tujuan dari pelaksanaan kegiatan ekstrakurikuler di sekolah menurut Direktorat Pendidikan Menengah Kejuruan :

1) Kegiatan ekstrakurikuler harus dapat meningkatkan kemampuan siswa yang beraspek kognitif, efektif, dan psikomotor.

2) Mengembangkan bakat dan minat siswa dalam upaya pembinaan pribadi menuju pembinaan manusia seutuhnya yang positif.

3) Dapat mengetahui, mengenal serta membedakan antara hubungan satu pelajaran dengan mata pelajaran lainnya.

\section{Kursus Kader Dakwah (KKD) \\ a. Konsep Dakwah}

Pengertian dakwah secara bahasa atau etimologi berasal dari bahasa Arab, yaitu da'a - yad'u $d a$ 'watan, yang artinya mengajak, menyeru dan memanggil. Warson Munawwir, menyebutkan dakwah adalahmemanggil, mengundang, mengajak, menyeru, mendorong, dan memohon. Dakwah adalah perbuatan mengajak manusia dengan cara bijaksana kepada jalan yang benar sesuai perintah Tuhan, untuk keselamatan dan kebahagiaan mereka di dunia. Selain itu menurut Natsir, dakwah yaitu usaha yang menyeru dan menyampaikan kepada perorangan manusia tentang pandangan dan tujuan hidup manusia di dunia ini yang meliputial-amr bi al- ma'ruf an-nahyu, an al-munkar dengan melewati berbagai macam cara dan media yang diperoleh akhlak dan membimbing pengalamannya dalam kehidupanbermasyarakat dan bernegara.

Tujuan dakwah secara global adalah agar manusia yang menerima pesan atau materi dakwah mendapatkan kebahagiaan di dunia maupun di akhirat. Abdul Halim Mahmud dalam Halimi,berpendapa mengenai tujuan dakwah sebagai berikut:

1) Membantu manusia untuk beribadah kepada Allah SWT sesuai dengan syariat.

2) Membantu manusia untuk saling mengenal satu sama lain dalam berinteraksi sosial di lingkungan masyarakat.

3) Merubah kondisi buruk yang dialami kaum muslim menjadi kondisi yang lebih baik dan benar.

4) Mendidik kepribadian muslim dengan pendidikan Islam yang benar.

5) Menyediakan tempat dan pendidikan bagi mereka sesuai dengan metode dan menejemen Islami.

6) Menyiapkan komunitas muslim yang berdiri atas dasa-rdasar budaya dan moralitas sesuai ajaran agama Islam.

7) Berusaha mewujudkan Negara Islam yang berdasarkan syariat Islam.

8) Berusaha mewujudkan persatuan Negara-negara Islam di dunia, sesuai kesatuan pemikiran dan budaya, kesatuan visi-misi, kesatuan ekonomi yang saling melengkapi, dan kesatuan politik.( Halimi, 2008 : 36)

\section{b. Pengertian Kursus Kader Dakwah}

Kursus adalah sebuah proses mengajarkan pengetahuan dan keahlian tertentu serta sikap agar seseorang semakin terampil dan mampu melaksanakan tanggung jawabnya dengan semakin baik, sesuai dengan standar (Syafri, 2003, 135). Kader adalah orang yang dididik untuk menjadi pelanjut tongkat estafet suatu partai atau organisasi (Maulana, 2004 : 194). Sedangkan dakwah menurut M. Arifin ( 2000 : 6) adalah suatu kegiatan ajakan baik dalam bentuk lisan, tulisan, tingkah laku yang dilakukan secara sadar dan berencana dalam mempengaruhi orang lain baik secara individu maupun kelompok agar timbul dalam dirinya kesadaran, sikap, penghayatan, serta pengamalan terhadap ajaran agama tanpa ada unsur pemaksaan.

Kaderisasi dakwah merupakan proses penurunan dan pemberian nilai-nilai yang berisi materi-materi pengetahuan dan wawasan, manajemen keorganisasian dan kepemimpinan tentang dakwah sebagai bagian dari mempersiapkan kader da'i (muballigh) di masa mendatang. Proses kaderisasi dakwah memerlukan waktu cukup panjang dan 
bertahap agar tercipta kader dakwah yang potensial dan berkualitas sesuai untuk meneruskan visi dan misi organisasi yang bersangkutan.

Jadi, Kursus Kader Dakwah adalah lembaga atau organisasi yang melatih dan memberikan pengetahuan seputar ilmu pengetahuan tentang dakwah untuk mencetak kader-kader atau generasi yang dapat melanjutkan dakwah Islamiyah.

\section{METODE}

Jenis penelitian ini adalah penelitian fenomenologik yaitu peneliti berusaha memahami arti dari berbagai peristiwa dalam setting tertentu dengan kacamata peneliti sendiri. Pendekatan ini dimulai dengan sikap diam ditunjukkan untuk menelaah apa yang sedang dipelajari. Cara fenomenologik menekankan berbagai aspek subjektif dari perilaku manusia, selanjutnya peneliti berusaha memahami bagaimana subjek memberi arti terhadap peristiwa yang terjadi disekitar kehidupannya, tugas utama fenomenologik adalah menangkap proses dan interpretasi.

Subjek dalam penelitian ini adalah kepala Madrasah, guru pembimbing dan siswa, objeknya adalah MAN 2 Model Medan yang bertempatkan di Jalan KKD di MAN 2 Model Medan Medanyang bertempatkan di Jalan Williem Islandar No. 7 A, Kelurahan Sidorejo, Kecamatan Medan Tembung, sedangkan yang ingin diteliti adalah kegiatan ekstrakurikulerKKD dalam membina kreativitas siswa. Tehnik pengumpulan data yang utama dalam penelitian ini adalah observasi,interview (wawancara), dan dokumentasi. Dalam penelitian ini metode yang digunakan dalam menganalisis data adalah dengan menggunakan teknik analisis data berdasarkan model miles dan hubermen, yaitu reduksi data, penyajian data, lalu kemudian penarikan kesimpulan.

Untuk mencapai trustworthiness (kebenaran), di pergunakan teknik kredibilitas, transferbilitas, dependabilitas, dan konfirmabilitas yang terkaitdengan dengan proses pengumpulan data. Kredibilitas menguji validitas data.Peneliti menerapkan teknik kredibilitas yaitu metode triangulasi.Peneliti menerapkan teknik Triangulasi Sumber.Teknik Triangulasi sumber yaitu teknik yang di gunakan untuk mencari data yang sejenis dengan mengecek data dari berbagai sumber informan. Dari data-data yang diperoleh tersebut, maka peneliti akan mudah untuk mendeskripsikan atau mengkategorikan mana pandangan yang sama, yang berbeda, maupun yang spesifik. Cara yang ditempuh untuk menjamin keteralihan (transferabilitas) adalah dengan melakukan uraian rinci dari data ke teori, sehingga pembaca dapat menerapkannya dalam konteks yang hamper sama. Dalam penelitian ini dependabilitas dibangun di bangun sejak dari pengumpulan data dan analisis data lapangan serta saat penyajian data laporan penelitian. Keabsahan data dan laporan penelitian ini dibandingkan dengan menggunakan teknik, yaitu: mengkonsultasikan setiap langkah kegiatan kepada promotor atau konsultan sejak dari pengembangan desain, menyusun ulang fokus, penentuan konteks dan narasumber, penetapan teknik pengumpulan dan analisis data serta penyajian data.Setiap data wawancara dan observasi dikonfirmasi ulang kepada informan kunci, dan subjek penelitian lainnya berkaitan dengan kebenaran fakta yang di temukan.

\section{IV.TEMUAN DAN HASIL PENELITIAN \\ 1.Temuan Umum}

Penelitian ini dilaksanakan di MAN 2 Model Medan yang berlokasi di Jalan Wiliem Iskandar No, 7 A, Kelurahan Sidorejo, Kecamatan Medan Tembung.MAN 2 Model Medan ini mendapatkan akreditasi A, dan sekarang di pimpin oleh Bapak Dr. H. Burhanuddin, M.Pd, sebagai kepala sekolah.

$\begin{array}{rrrr}\text { MAN 2 } & \begin{array}{l}\text { Model } \\ \text { terus }\end{array} \\ \text { berkesinambungan } & \text { berpacu } & \text { secara } \\ \text { dalam }\end{array}$
meningkatkan kualitas pelayanan dan pelaksanaan pendidikan dalam mencapai tujuan visi dan misinya. Sehingga sampai saat ini telah menjadi salah satu sekolah yang unggul, terfavorit di kecamatan Medan Tembung dan menarik minat masyarakat luas.Di MAN 2 Model Medan ini siswa di arahkan dan di bina untuk dapat memiliki kemantapan dalam berakhlaqul karimah (Emotional Quotient), kemantapan pribadi, berkarakter, berprestasi, dan memiliki keluasan IPTEK (Intelegency Quotient).

\section{Temuan Khusus}

Pembahasan hasil penelitian dimulai dari observasi, wawancara dan dokumentasi.Data yang telah diperoleh dari hasil observasi, wawancara dan dokumentasi selanjutnya di telaah dan dianalisis. Dalam penelitian yang peneliti lakukan peneliti menganalisis apapun yang berkenaan tentang kegiatanpelaksanaan pebinaan kreativitas siswadalam kegiatan ekstrakurikuler KKD diantaranya:

\section{a. Program Kegiatan Ekstrakurikuler KKD di MAN 2 Model Medan}

Program yang dimaksudkan disini adalah jenis jenis kegiatan ekstrakurikuler bidang keagamaan dan Dakwah, meliputi Bentuk aktivitas KKD di MAN 1 Medan yang dapat mengembangkan bakat siswa antara lain :

1) Mentoring/Halaqoh

2) Pelatihan Pidato

3) Tahsin Alquran

4) Pelatihan Public Speaking Training

5) Pelatihan Menulis/Jurnalistic Training 
6) Silaturrahmi Ukhwah

7) Gebyar Kreativitas Muharram

8) Safari Ramadhan

9) Rihlah

Hal tersebut sesuai dengan hasil wawancara peneliti dengan Bapak Muhammad Al-Haris Shihab selaku Ketua KKD disekolah tersebut. Dalam wawancaranya berisi sebagai berikut:

"Jenis kegiatan Kursus Kader Dakwah terdiri dari dua, yaitu mingguan dan bulanan.Kegiatan mingguannya seperti Mentoring/Halaqoh, Pelatihan Pidato dan Tahsin Alquran.Sedangkan kegiatan bulanannya seperti Pelatihan Public Speaking Training, Pelatihan Menulis/Jurnalistic Training. Kemudian ada juga Silaturrahmi Ukhwah, baik itu di sekolah-sekolah yang memiliki Rohani Islam (Rohis) maupun di MAN-MAN lain. Kemudian kami juga membuat kegiatan gebyar kreativitas untuk di bulan Muharram, Safari Ramadhan, dan Rihlah (Jalanjalan)."

Hal yang sama juga diungkapkan oleh Bapak Wahyu selaku pendidikpada ekstrakurikuler KKD :

"Kalau dari jenis kegiatannya bermacammacam.Yang pasti dari kategori pengembangan individu yang ada di KKD itu sendiri. Seperti pengembangan sisi keilmuannya dan seperti yang baru dilaksanakan 2 minggu yang lalu yaitu pelatihan jurnalistik, dan kemudian ada juga kegiatan untuk menambah semangat individu dengan mengadakan training motivasi, kemudian ada kegiatan-kegiatan yang lain seperti pidato, tahsin, fahmil Alquran dll."

Dari hasil wawancara yang peneliti lakukan kepada ketua KKD dan pendidikpada ekstrakurikuler KKD, maka dapat disimpulkan bahwa program kegiatan ekstrakurikuler KKDdi MAN 2 Model Medandalam pembinaan kreativitas siswa terdiri dari dua kegiatan program, yaitu mingguan dan bulanan. Kegiatan mingguannya seperti Mentoring/Halaqoh, Pelatihan Pidato dan Tahsin Alquran. Sedangkan kegiatan bulanannya seperti Pelatihan Public Speaking Training, Pelatihan Menulis/Jurnalistic Training.

\section{b. Peluang dan Hambatan KegiatanEkstrakurikuler KKD di MAN 2 Model Medan}

Berdasarkan hasil wawancara dengan beberapa pembina dan pendidik kegiatan ekstrakurikuler KKD dapat disimpulkan bahwa peluang dalam kegiatan ekstrakurikuler KKDsangat besar, diantaranya yaitu :

1) Menjadi Da'i dan Muallim di daerahnya

2) Menjadi Ulama Istiqomah

3) Menjadi Tokoh Nasional
4) Motivator

5) Instruktur Kegiatan

Dan hambatan yang tidak terlalu berarti dalam kegiatan ekstrakurikuler KKD, yaitu :

1) Sikap apatis masyarakat terhadap gerakan dakwah

2) Segi Keanggotaan

3) Penditraan Da'i

Hal tersebut sesuai dengan hasil wawancara peneliti dengan Bapak Muhammad Al-Farabi M.Ag selaku pembina KKD disekolah tersebut. Dalam wawancaranya berisi sebagai berikut:

"Kalau peluang mereka ini saya yakin dengan kesungguhan dan keberanian mereka, mereka akan bisa menjadi $D a^{\prime} i-D a^{\prime} i$ yang ternama di masyarakat.Sekaligus juga bisa menjadi Muallim kampung bagi merka yang mempunyai kampung halamannya. Kemudian mereka juga nanti Insya Allah bisa mnjadi Ulama-ulama yang ke depan yang Istiqomah dalam memegang ajaran Islam. Kemudian mereka ini juga tidak menutup kemungkinan mereka juga bisa menjadi tokoh di kota Medan, maupun Sumatera Utara bahkan Nasional. Karena mereka ini sudah dibekali dengan berbagai lintas kemampuan.Jadi mereka tidak hanya bisa berdakwah saja.Mereka juga mampu menjadi motivator, menjadi istruktur kegiatan, dan juga mampu menulis karya karya ilmiah Islam serta berita-berita Islam.Kemudian mereka juga mampu bersosialisasi dengan masyrakat dan ini adaah modal utama dalam pengembangan diri di tengah masyarakat."

"Kalau hambatan tidak begitu berarti. Palingpaling nanti ketika mereka terjun ke masyarakat mereka akan menghadapi sikap apatis dari masyarakat terhadap gerakan dakwah. Dan yang perlu kita waspadai adalah pencitraan $\mathrm{Da}^{\prime} \mathrm{i}$ di masyarakat itu sudah mulai melemah setelah adanya isu-isu bahwa para Penda'i dan Ustad-ustad itu ada yang terlibat dalam jaringan teroris dan ini sebenarnya isu-isu dari kaum-kaum yahudi dan kaum-kaum luar untuk merusak citra Penda'i di masyarakat. Contoh kecilnya saja, walaupun KKD tidak dilakukan di masyarakat, sebagian Rohani Islam (Rohis) yang berkembang di SMA itu ada yang sudah dinodai citranya oleh kaum-kaum yang tidak bertanggung jawab yang mengklaim mereka itu sebagai kelompok yang memiliki paham ekstrim di tengah-tengah masyarakat. Sebenarnya itu hanya kekeliruan saya yang tidak dapat dibuktikan kebenarannya.Jadi hambatannya adalah ketika menghadapi sikap-sikap mental masyarakat saja.Kalau di MAN 2 hampir dikatakan tidak ada.Kalau masalah keuangan masih bisa diatasi oleh pihak komite dan keuangan sekolah." 
Hal ini sejalan dengan hasil wawancara dengan Saudara Muhammad Al-Haris Shihab selaku ketua KKD dengan pertanyaan yang sama, beliau mengemukakan bahwa :

"Peluang dalam ekstrakurikuler Kursus Kader Dakwah ini sangat besar karena sekolah pun mendukung pelaksanaan Kegiatan Ekstrakurikuler Kursus Kader Dakwah ini.Sedangkan hambatannya adalah dari segi keanggotaan. Saya rasa dari segi anggotanya ada yang mengikuti organisasi lain. Sehingga kurang efektifnya pelaksanaan Kursus Kader Dakwah ini.Sedangkan hambatannya adalah dari segi keanggotaan. Saya rasa dari segi anggotanya ada yang mengikuti organisasi lain. Sehingga kurang efektifnya pelaksanaan Kursus Kader Dakwah ini”.

Hal ini sejalan dengan yang peneliti lihat dilapangan pada kegiatan KKD dalam melaksanakan pebinaan kreativitas siswa ada peluang yang sangat besar dan hampir tidak ada hambatan yang pasti di dalam pelaksanaanya.

\section{ANALISIS PEMBAHASAN}

Proses pembahasan hasil penelitian dimulai dengan menelaah seluruh data yang tersedia dari berbagai sumber hasil observasi/pengamatan langsung, wawancara dan dokumentasi. Pembahasan hasil penelitian juga berarti proses berkelanjutan selama penelitian langsung.

Dalam penelitian ini peneliti memiliki analisis selama menjalankan penelitian tentang pelaksanaan ekstrakurikuler Kursus Kader Dakwah dalam membina kreativitas siswa/i memerlukan proses yang panjang dan berkelanjutan. Pelaksanaan kegiatan ekstrakurikuler Kursus Kader Dakwah ini tidak lepas dari peran kepala madrasah, pembina ekstrakurikuler Kursus Kader Dakwah, pendidik ekstrakurikuler Kursus Kader Dakwah, dan ketua ekstrakurikuler Kursus Kader Dakwah dalam menanamkan nilai-nilai ajaran Islami yang dapat menambah wawasan keislaman mereka. Tidak hanya itu, Siswa/i MAN 2 Model Medan yang mengikuti ekstrakurikuler Kursus Kader Dakwah ini juga diberikan pelatihan dalam bentuk life skill mereka seperti jurnalistik, public speaking training, dan motivasi yang dapat membuat mereka mampu memilki pengetahuan yang dapat menunjang kelancaran dalam efektifitas dakwah saat mereka berdakwah di lingkungan sekolah maupun di lingkungan masyarakat.

Dalam penelitian ini, peneliti memiliki analisis menyangkut kreativitas siswa/i yang mengikuti pelaksanaan kegiatan ekstrakurikuler Kursus Kader Dakwah yaitu dengan adanya kemampuan kreativitas siswa dalam berdakwah sesuai dengan permasalahan yang terjadi pada saat ini yang menyangkut tentang Islam, selain itu juga adanya kreativitas siswa/i dalam mengadakan pelatihan-pelatihan jurnalistik, public speaking training terhadap adik-adik kelasnya maupun pada saat berada di lingkungan masyarakatnya.

Secara Umum pelaksanaan kegiatan ekstrakurikuler Kursus Kader Dakwah di MAN 2 Model ini sudah berjalan dengan baik.Hal ini bisa peneliti lihat dari segi pendidik, peserta didik, materi, metode dan medianya.Dan peneliti juga mengamati bahwa peluang pelaksanaan kegiatan ekstrakurikuler Kursus Kader Dakwah ini sangat besar.Hal ini terlihat dari ajaran yang terkandung di dalam ekstrakurikuler Kursus Dakwah ini mendukung wawasan keilmuan agama Islam siswa/i. Hal ini sejalan dengan Madrasah yang memiliki nuansa Islami di dalam pelaksanaan pendidikannya.Sedangkan dalam hambatannya tidak ditemukan hal-hal penghambat yang begitu besar.Bahkan bisa dikatakan masih sangat bisa diatasi oleh pihak sekolah.

\section{KESIMPULAN}

Berdasarkan uraian yang ada di atas tentang pelaksanaan kegiatan ekstrakurikuler Kursus Kader Dakwah dalam membina kreativitas siswa dapat disimpulkan bahwa :

a.Keberadaan ekstrakurikuler Kursus Kader Dakwah cukup eksis dan baik. Bahkan ekstrakurikuler Kursus Kader Dakwah ini merupakan salah satu ekstrakurikuler terfavorit dari 48 ekstrakurikuler yang ada di MAN 2 Model Medan.

b.Jenis kegiatan ekstrakurikuler Kursus Kader Dakwah juga cukup banyak. Diantaranya ada Mentoring, Tahsin dan Fahmil Alquran, Pidato, Public Speaking Training, Jurnalistik, dan Motivasi. Dan pelaksanaanya sudah ditentukan waktunya. Yaitu pada hari jum'at, sabtu, dan minggu.

c.Peluang dalam pelaksanaan kegiatan ekstrakurikuler Kursus Kader Dakwah ini sangat besar. Hal ini dapat dilihat dari potensi siswa/inya serta dukungan dari pihak madrasah. Sedangkan hambatannya tidak terlalu dominan. Bahkan dikatakan masih bisa diatasi oleh pihak madrasah.

\section{DAFTAR PUSTAKA}

Arifin, M. (2000). Psikologi Dakwah Suatu

Pengantar Studi. Jakarta: Bumi Aksara

Halimi, Safrodi. (2008). Etika Dakwah dalam

Perspektif Al Quran. Semarang: Walisog Pers

Mangkuprawir, Syafri. (2003). Manajemen

Sumber Daya Manusia Staregi. Jakarta: Glalia Indonesia

Maulana, Ahmad. (2004). Kamus Ilmiah Populer. Yogyakarta: Absolut

Munanadar, Utami. (2016). Pengembangan Kreativitas Anak Berbakat. Jakarta: Rineka Cipta 
Permana, Johar. (2012). Manajemen Ekstrakurikuler. Jakarta: Rineka Cipta Ramayulis. (2005). Metpodologi Pendidikan Agama Islam. Jakarta: Kalam Mulia
Sagoya (1995). Kamus Indonesia Kontemporer. Bandung: Karya Nusantara 